Loyalitas Kreativitas
Aldi Masyarakat Kreatif

P-ISSN 2722-2101, E-ISSN 2722-4201

Program Studi Ekonomi Manajemen Universitas Pamulang

Jurnal LOKABMAS Kreatif Vol. 01, No. 03, Hal. 7-15

Email:jurnalkreatif.manajemen@gmail.com

\title{
MEMBENTUK ENTREPRENEUR GENERASI MUDA UNTUK MEMBANGUN PERCAYA DIRI DALAM MENGHADAPI TANTANGAN MASA DEPAN PADA YAYASAN ISHLAHUL HAYAT RUMAH YATIM \& DHUAFA KELURAHAN BAMBU APUS KECAMATAN PAMULANG TANGERANG SELATAN
}

\author{
Maswarni, Jeni Andriani, Retno Wulansari, \\ Sri Retnaning Sampurnaningsih, Novia Susanti \\ Dosen Prodi Manajemen Fakultas Ekonomi Universitas Pamulang \\ Email : dosen00381@unpam.ac.id,dosen00436@unpam.ac.id, dosen00568@unpam.ac.id, \\ dosen01366@unpam.ac.id, dosen00768@unpam.ac.id
}

\begin{abstract}
ABSTRAK
Pengabdian kepada masyarakat (PKM), mempunyai tema "Membentuk Entrepreneuer Generasi Muda untuk Membangun Percaya Diri Dalam Menghadapi Tantangan Masa Depan", Pada Yayasan Ishlahul Hayat, Rumah Yatim \& Dhuafa Kelurahan Bambu Apus Kecamatan Pamulang Tangerang Selatan.

Tujuan dari Pengabdian kepada Masyarakat (PKM) ini adalah untuk membentuk entrepreneur muda, dengan cara membangun percaya diri, sehingga dapat menghadapi tantangan masa depan. Pengabdian dilakukan kepada para guru dan anak didik/asuhan Yayasan Ishlahul Hayat melalui penyuluhan mengenai motivasi dan kreatifitas, serta pembuatan kerajinan (craft) decoupage. Adapun mitra PKM adalah Yayasan Ishlahul Hayat, Rumah Yatim \& Dhuafa di Jalan Mujair Raya Kelurahan Bambu Apus Kecamatan Pamulang Tangerang Selatan.

Metode yang digunakan dalam PKM ini adalah penyuluhan tentang motivasi dan kreatifitas serta pelatihan membuat kerajinan (craft) decoupage.

Hasil dari pelaksanaan PKM ini, diharapkan anak asuhan Yayasan Ishlahul Hayat, Rumah Yatim \& Dhuafa di Jalan Mujair Raya Kelurahan Bambu Apus Kecamatan Pamulang Tangerang Selatan mampu membuat kerajinan (craft) decoupage sehingga dapat membentuk entrepreneur yang terampil, mandiri dan kreatif, serta dapat meningkatkan percaya diri serta siap menghadapi tantangan masa depan, menuju kehidupan yang lebih cemerlang.
\end{abstract}

\section{Kata Kunci: Entrepreneur, Percaya Diri, Tantangan Masa Depan, Decoupage}

ABSTRAC

The service has theme "How to Build Up Young Generation Entrepreneurs Who Confidence in Facing Future Challenges, at Ishlahul Hayat Foundation, Rumah Yatim \& Dhuafa, Bambu Apus Village, Pamulang, South Tangerang.

The purpose of this service is to build up young generation entrepreneurs who confidence in facing future challenges, which subject are teacher and students of Ishlahul Hayat Foundation through sharing session and discussion about motivation, creativity, and how to make a craft with "decoupage technique". The service partner is Ishlahul Hayat Foundation, Rumah Yatim \& Dhuafa which have an address at Jalan Mujair Raya, Kelurahan Bambu Apus, Pamulang, South Tangerang.

The method used in this service were sharing session and discussion about motivation, creativity and training how to make a craft with decoupage technique. 


\section{Loyalitas Kreativitas Aldi Masyarakat Kreatif}

P-ISSN 2722-2101, E-ISSN 2722-4201

Program Studi Ekonomi Manajemen Universitas Pamulang

Jurnal LOKABMAS Kreatif Vol. 01, No. 03, Hal. 7-15

Email:jurnalkreatif.manajemen@gmail.com

The result of this activities are teacher and students of Yayasan Ishlahul Haya, Rumah Yatim \& Dhuafa which address at Jalan Mujair raya, Kelurahan Bambu Apus, South Tangerang, through sharing session and discussion, able to make a craft with decoupage technique, skillful, independent, and creative, therefor they will be as young entrepreneurs who confidence in facing a future challenges to get a better \& quality of life.

\section{Keywords: Entrepreneur, Confidence, Future Challenges, Decoupage}

\section{PENDAHULUAN}

Yayasan Ishlahul hayat adalah lembaga sosial yang bergerak pada bidang sosial keagamaan dan bidang pendidikan anak-anak asuh. Selain kegiatan tersebut juga mengelola dana zakat, infaq Sedekah, wakaf baik perorangan, kelompok maupun perusahaan/lembaga untuk disalurkan secara lebih tepat sasaran dengan menitik beratkan pada anak anak asuh yatim dan dhuafa terutama dibidang kebutuhan pokok dan pendidikan. Tujuan lain program ini didirikan adalah dalam rangka ikut membantu pemerintah untuk menjadi fasilitator antara mudahi dan mustahik serta menjadi pelayanan masyarakat dalam bidang sosial kemasyarakatan, dan berlokasi di Jalan Mujair raya, Kelurahan Bambu Apus, Kecamatan Pamulang, Tangerang Selatan.

Rumah Asuh Yayasan Ishlahul Hayat memulai kiprahnya sejak tahun 2017 dengan jumlah anak asuh sebanyak 27 anak asuh.

Saat ini dan masa yang akan datang, membuka lapangan pekerjaan sendiri adalah hal yang sangat dianjurkan. Program entrepreneurship mulai digalakkan untuk membuat generasi muda dapat bekerja dan menciptakan kreasi produktif, tanpa harus berpaku dengan bekerja perusahaan besar atau menjadi pegawai negeri.

Agar seorang entrepreneur bisa sukses dalam usahanya, mereka harus memiliki lima hal penting, yaitu motivasi, kreatifitas, mampu bekerjasama dengan orang lain, memiliki visi dan berpikiran terbuka.

Kami dari pihak dosen Universitas Pamulang, terpanggil untuk memberikan kontribusi dalam membina generasi muda yang lebih tangguh dan percaya diri dalam menghadapai tantangan masa depan, sehingga generasi muda mendapatkan kehidupan yang lebih baik dan berkualitas.Oleh karena itu, diperlukan pembinaan untuk meningkatkan dan mengembangkan kemampuan dan kepribadiannya,, dalam bidang:

1. Mental spiritual meliputi sikap dan perilaku sebagai Insan hamba Tuhan, anggota masyarakat dan warga negara yang dinamis serta bermanfaat, berdasarkan Pancasila dan UndangUndang Dasar 1945.

2. Fisik material meliputi pangan, sandang, papan, kesehatan, kesempatan kerja yang layak serta lingkungan hidup yang sehat dan lestari melalui peningkatan pendidikan, pengetahuan dan keterampilan.

Berlandaskan analisa situasi tersebut, dimana yayasan Islahul Hayat yang memberikan fasilitas tempat tinggal, pendidikan dan pelatihan serta pendidikan agama untuk anak-anak asuh Yatim dan dhuafa,memerlukan dukungan dan kerjasama dengan para akademisi untuk membimbing dan dan memberikan pembekalan kepada anak-anak asuh mereka, sehinggs menjadi generasi muda yang lebih mandiri dan percaya diri dalam menghadapi tantangan masa depan.

\subsection{RUMUSAN MASALAH}

Adapun perumusan masalah adalah :

1. Bagaimana membentuk enterpreneur pada anak-anak Asuhan Yayasan Ishlahul Hayat? 
2. Bagaimana membangun percaya diri pada anak-anak asuhan Yayasan Ishlahu Hayat?

3. Bagaimana membentuk entrepeneur dalam membangun percaya diri melalui pelatihan kerajinan (craft) decoupage pada anak-anak asuhan Yayasan Ishlahul Hayat?

\subsection{TUJUAN PELAKSANAAN}

1. Untuk membentuk enterpreneur pada anak-anak asuhan Yayasan Ishlahul Hayat.

2. Untuk membangun percaya diri anak-anak asuhan Yayasan Ishlahul Hayat.

3. Untuk membentuk entrepeneur dan membangun percaya diri melalui pelatihan kerajinan (craft) decoupage pada anak-anak asuhan Yayasan Ishlahul Hayat.

\subsection{MANFAAT PELAKSANAAN}

Manfaat dari adanya kegiatan ini adalah :

1. Manfaat bagi masyarakat umum yaitu, diharapkan dapat menjadikan masyarakat mandiri dan sejahtera

2. Manfaat bagi anak asuhan Yayasan Ishlahul Hayat yaitu untuk membentuk jiwa entrepreneur sehingga menumbuhkan rasa percaya diri

3. Manfaat bagi para dosen dan mahasiswa selaku pelaku Pengabdian kepada Masyarakat, dapat berbagi pengetahuan terkait dengan ilmu manajemen, kewirausahaan, dalam mewujudkan masyarakat yang mandiri dan sejahtera

\section{TINJAUAN PUSTAKA}

\section{1..Entrepeneur}

berani $\begin{gathered}\text { Entrepreneur adalah orang yang } \\ \text { menciptakan peluang dan }\end{gathered}$ mengambil resiko tertentu untuk membuat suatu usaha sendiri. Dalam hal ini tujuan yang dicapai adalah untuk mendapatkan nilai-nilai perekonomian yang menunjang. Baik itu untuk wirausaha sendiri, maupun untuk orang lain yang terikat dengan usaha tersebut

Menurut, Thomas W. Zimmerer (2008) arti entrepreneurship (kewirausahaan) adalah penerapan kreativitas dan keinovasian untuk memecahkan permasalahan dan upaya memanfaatkan peluang-peluang yang dihadapi orang setiap hari.

Seringkali entrepreneurship dimaknai secara sempit sehingga pembelajaran mengenainya di institusi pendidikan menjadi kurang tepat. Entrepreneurship biasanya diajarkan hanya sebatas bagaimana menjadi pengusaha sehingga lupa esensinya. Dr. Riant Nugroho, Direktur Institute for Policy Reform dalam esainya yang berjudul Tantangan Pendidikan Terkini: Membangun "Entrepreneur", menuliskan 2 cara efektif untuk mengajarkan entrepreneurship di sekolah:

1. Entrepreneurship Sebagai Nilai Riant Nugroho menyatakan bahwa entrepreneurship bukanlah pengetahuan tentang pengusaha dan menjadi pengusaha, juga bukanlah sebuah cara untuk menjadi pengusaha dan mendirikan usaha. Akan tetapi, entrepreneuship adalah sebuah nilai untuk menemukan sesuatu yang baru dan bermanfaat bagi masyarakat luas.

Selama para pengajar menjadi sosok yang ditakuti di ruang kelas dan tidak terbuka terhadap pertanyaan dan ide-ide yang out of the box, maka nilai ini yang menjadi substansi dari entrepreneurship akan hilang. Oleh karena itu, diperlukan ruang kelas yang sangat terbuka untuk berdiskusi tentang hal-hal baru.

Tiga Macam Entrepreneur 
a. Entrepreneurship = just selling, seperti orang yang mengambil sebuah produk dari produsen dan kemudian menjualnya kepada konsumen. Mereka mendapat keuntungan hanya dari selisih harga jual dan beli. Contohnya, pedagang sayur dan buah di pasar tradisional dan pedagang warung kelontong. jenis ini bukan entrepreneur melainkan preentrepreneur.

b. Entrepreneur = value added, seperti orang yang tidak hanya membeli sebuah barang dan menjualnya kembali tapi memberikan nilai tambah yang membuat harga jualnya meningkat beberapa kali lipat daripada harga asalnya. Contohnya, pedagang bakso yang sebelumnya membeli bahan-bahan untuk diolah menjadi bakso.

c. Real entrepreneur = value creator. Mereka adalah orang yang mendapatkan keuntungan dari hasil inovasinya yang diapresiasi dan menjadi solusi baru bagi kehidupan masyarakat luas. Contohnya, Bill Gates penemu Microsoft dan Steve Jobs penemu Apple yang berhasil menggabungkan fungsi komputer, telepon genggam, buku, kamera, dan gawai lain menggunakan bantuan teknologi

2. Entrepreneurship Sebagai Konsep Berjenjang

Beberapa jenjang untuk memahami entrepreneurship sebagai satu kesatuan konsep sering kali dilupakan. Riant Nugroho memaparkan lima jenjang untuk satu kesatuan konsep tersebut. a. Kegiatan (Activity), adalah seseorang atau kelompok orang yang melakukan kegiatan usaha. Ini merupakan pemahaman paling umum yang sudah diketahui oleh banyak orang dan seringkali disalahartikan sebagai satusatunya makna mengenai entrepreneurship dan entrepreneur.

b. Ketrampilan (Skill), adalah makna yang lebih dalam daripada sekedar kegiatan, yaitu menggunakan ketrampilannya untuk terjun dalam dunia entrepreneurship.

c. Profesi (Profession), adalah pemahaman bahwa beberapa dari mereka harus dipahami bukan hanya sebagai pemilik usaha saja tapi juga sebagai pengelola usaha profesional.

d. Orientasi (Orientation), adalah pemahaman bahwa entrepreneurship merupakan orientasi atau cara pandang. Berorientasi kepada peluang yang juga memberikan manfaat kebaikan kepada masyarakat luas.

e. Nilai (Values), merupakan bagian terpenting - sama seperti pada nomor satuadalah pemahaman bahwa entrepreneuship adalah sebuah nilai. Nilai yang harus selalu terus diperjuangkan dan dikembangkan bukan hanya sesuatu yang dipertahankan ketika dianggap sudah jadi.

\subsection{Percaya diri}

Percaya diri adalah sikap positif seorang individu yang memampukan dirinya untuk mengembangkan penilaian positif baik terhadap diri sendiri maupun terhadap lingkungan atau situasi yang dihadapinya. dimana ia merasa memiliki 
kompetensi, yakin, mampu dan percaya bahwa dia bisa karena didukung oleh pengalaman, potensi aktual, prestasi serta harapan yang realistik terhadap diri sendiri.

Percaya diri merupakan salah satu aspek kepribadian yang sangat penting dalam kehidupan manusia. Orang yang percaya diri yakin atas kemampuan mereka sendiri serta memiliki pengharapan yang realistis, bahkan ketika harapan mereka tidak terwujud, mereka tetap berpikiran positif dan dapat menerimanya.

Wirausahawan memiliki enam tema karakter utama yang membentuk akronim:

$\mathrm{F}$ (Focus) untuk fokus,

A (Advantage) untuk keuntungan,

C (Creativity) untuk kreativitas,

E (Ego) untuk ego,

$\mathrm{T}$ (Team) untuk tim,

S (Social) untuk sosial.

Memulai usaha

\subsection{Tantangan masa depan}

Pada saat ini di zaman era modern begitu luar biasanya tantangan yang di hadapi dari berbagai sektor ,bukan hanya dari segi teknologi saja,tetapi nilai -nilai baik dari segi sosial,ekonomi ,politik dan lain -lain. Hingga kini bangsa Indonesia masih mencari sosok pemuda yang memiliki fondasi dasar nilai-nilai pancasila yang mampu memelihara nilai luhur bangsa Indonesia agar dapat di lanjutkan kepada generasi muda yang lain dalam rangka menuju masyarakat yang modern.

Masa depan sangat ditentukan dari bagaimana pemuda bertindak. Lantas yang menjadi pertanyaan, bagaimanakah peran pemuda Indonesia saat ini, dan harapan untuk generasi muda ke depannya?

Pemuda merupakan muara bangsa Indonesia, memiliki peran yang sangat penting dalam

Sebagai agent of change diharapkan pemuda dapat bersatu dan maju secara bersama-sama untuk menghadapi globalisasi yang akan terus tumbuh dan berkembang. Pemuda Indonesia memiliki tanggung jawab yang besar seiring waktu, oleh karena itu pemuda Indonesia harus tangguh secara intelektual dan moralis.

Jangan sesekali terlena oleh banyak kemudahan dan kenyamanan saat ini, karena sesungguhnya saat inipun globalisasi terus tumbuh dan berkembang. Mencontoh semangat pemuda masa lalu yang tak gentar untuk terus mencoba membawa perubahan-perubahan demi bangsa Indonesia.

\subsection{Kerajinan Decoupage}

Decoupage adalah seni kerajinan dari Perancis yang masuk ke Indonesia sebelum tahun 2000. Decoupage adalah seni melapis barang dengan menggunakan tisu impor dengan berbagai media yaitu clutch pandan, gantungan kunci, tatakan gelas, kaleng mini, kotak perhiasan, jam kayu, talenan kayu hiasan dinding, gelas kaca, botol, kalung mutiara (teknik suspenso), stoples, piring, tas kain, dan kanvas lukis. (Hendraidjat, 2016)

Decoupage juga dikenal sebagai seni dekorasi dengan cara menempel potongan-potongan kertas pada permukaan sebuah benda, kemudian dicat untuk memberikan efek yang diinginkan. Kemudian tidak lupa divarnish agar potongan kertas seolaholah benar2 menyatu dengan objek tersebut. Kegiatan varnish ini dapat dilakukan berlapis-lapis sehingga mendapatkan efek menyatu.

\section{MATERIDANMETODE PELAKSANAAN}

\subsection{KERANGKAPEMECAHAN MASALAH}


Solusi yang diusulkan atau ditawarkan dalam kegiatan PKM ini adalah sebagai berikut:

\section{Aspek manajemen}

Sesuai dengan permasalahan yang dihadapi oleh mitra maka solusi untuk aspek manajemen adalah memberikan penyuluhan tentang manajemen meliputi manajemen pemasaran, sumber daya manusia, keuangan dan produksi/operasional.

2. Aspek usaha

Solusi yang ditawarkan untuk mitra adalah memberikan pelatihan usaha yaitu dengan cara membuat kerajinan (craft) decoupage dari kertas tisu pada berbagai bahan seperi tas, dompet, kotak pensil dan tempat tissue anyaman.

\subsection{REALISASI MASALAH}

\begin{tabular}{ccc}
\multicolumn{2}{c}{ Berdasarkan solusi } & yang \\
diusulkan maka target & yang
\end{tabular} diharapkan sebagai berikut:

1. Aspek entrepreneur

Anak asuhan Yayasan Ishlahul Hayat diharapkan mampu dan berani menciptakan peluang dan mengambil resiko tertentu untuk membuat suatu usaha sendiri. Dalam hal ini tujuan yang dicapai adalah untuk mendapatkan nilainilai perekonomian yang menunjang. Baik itu untuk wirausaha sendiri, maupun untuk orang lain yang terikat dengan usaha tersebut.

2. Membangun rasa pecaya diri Membangun rasa percaya diri yaitu sikap positif seorang individu yang memampukan dirinya untuk mengembangkan penilaian positif baik terhadap diri sendiri maupun terhadap lingkungan atau situasi yang dihadapinya. dimana ia merasa memiliki kompetensi, yakin, mampu dan percaya bahwa dia bisa karena didukung oleh pengalaman, potensi aktual, prestasi serta harapan yang realistik terhadap diri sendir Salah satunya adalah menambahkan keahlian dengan mempraktekkan cara membuat kerajinan (craft) decoupage dari kertas tisu pada berbagai bahan, seperi tas dan dompet amyaman dan sampai memasarkan produk tersebut

3. Pada saat ini di zaman era modern begitu luar biasanya tantangan yang di hadapi dari berbagai sektor ,bukan hanya dari segi teknologi saja, tetapi nilai nilai baik dari segi sosial,ekonomi ,politik dan lain lain., bangsa Indonesia masih mencari sosok pemuda yang memiliki fondasi dasar nilai-nilai pancasila yang mampu memelihara nilai luhur bangsa Indonesia agar dapat di lanjutkan kepada generasi muda yang lain dalam rangka menuju masyarakat yang modern.dan mandiri

\subsection{KHALAYAK SASARAN}

Peserta kegiatan : Anak - anak asuhan pada Yayasan Ishlahul Hayat

\subsection{TEMPAT DAN WAKTU}

Tempat Kegiatan : Rumah Yatim \& Dhuafa Di Jalan Mujair Raya Kelurahan Bambu Apus Kecamatan Pamulang Tangerang Selatan

Waktu Pelaksanaan

: Sabtu -

Minggu, 11 - 12 Juli 2020

Jam 09.00 - 15.00 WIB

\subsection{METODE KEGIATAN}

Metode yang digunakan dalam kegiatan Pengabdian Kepada Masyarakat ini adalah penyuluhan tentang entrepreneur dan praktek pembekalan anak asuhan Yayasan Ishlahul Hayat dengan kerajinan (craft) decoupage. Pengabdian dibagi menjadi dua yaitu tahap persiapan dan tahap pelaksanaan. 


\section{Loyalitas Kreativitas \\ Aldi Masyarakat Kreatif}

P-ISSN 2722-2101, E-ISSN 2722-4201

Program Studi Ekonomi Manajemen Universitas

Pamulang

Jurnal LOKABMAS Kreatif Vol. 01, No. 03, Hal. 7-15

Email:jurnalkreatif.manajemen@gmail.com
Tahap persiapan, meliputi:

a) Observasi dan survei ke Yayasan Ishlahul Hayat di Jalan Mujair Kelurahan Bambu Apus Kecamatan Pamulang Tangerang Selatan termasuk pengurusan perijinan untuk melaksanakan kegiatan Pengabdian Kepada Masyarakat.

b) Pemantapan konsep Pengabdian Kepada Masyarakat yang berupa penyuluhan manajemen usaha disertai pembekalan kerajinan (craft) decoupage, kepada anak asuhan Yayasan Ishlahul Hayat di jalan Mujair Kelurahan Bambu Apus Kecamatan Pamulang Tangerang Selatan. Pembuatan instrumen pelaksanaan kegiatan Pengabdian Kepada Masyarakat, berupa handout presentasi dan sampel praktek kerajinan (craft) decoupage.

d) Persiapan alat dan bahan, terdiri dari:

1) Alat dan bahan presentasi

2) Alat dan bahan pembuatan praktek kerajinan (craft) decoupage.

Metode kegiatan ini berupa penyuluhan dan pelatihan keterampilan usaha. Berikut ini adalah tahapan yang dilakukan :

\section{Tahap Persiapan}

Tahap persiapan yang dilakukan meliputi :

a. Informasi awal, pada tahap ini di dapatkan infomasi awal dari dosen Tim PKM, yaitu Ibu Novia Susanti, S.E., M.M.

b. Pemantapan dan penentuan lokasi dan sasaran. Setelah informasi awal maka ditentukan lokasi pelaksanaan dan sasaran peserta kegiatan penyuluhan manajemen usaha disertai praktek kerajinan (craft) decoupage, pada Yayasan Ishlahul Hayat Rumah Yatim \& Dhuafa Di Jalan Mujair Raya Kelurahan
Bambu Apus Kecamatan Pamulang Tangerang Selatan.

c. Penyusunan

bahan/materimotivasi dan penyuluhan dan pelatihan yang meliputi: slide dan makalah/materi untuk kegiatan pelatihan keterampilan usaha (praktek kerajinan decoupage)

2. Tahap Pelaksanaan Penyuluhan

Tahap ini akan menjelasan tentang keretifitas, jiwa enterprneur dari mulai usia muda, membantu/meningkatkan percaya diri memiliki kereatifitas dan jiwa enterpreneur, selanjutnya dilakukan tahap diskusi dan tanya jawab.

\section{Tahap Pelatihan/Praktek}

Untuk melaksanakan kegiatan tersebut digunakan beberapa metode pelatihan, yaitu :

a. Metode Demonstrasi

Metode demonstrasi ini menunjukkan contoh kepada para peserta untuk mengerjakan/praktek membuat kerajinan (craft) decoupage dari kotak pensil dan ; pouch anyaman.

b. Metode Tanya Jawab

Metode tanya jawab sangat penting bagi para peserta pelatihan. Metode ini memberi kesempatan kepada peserta untuk menanyakan hal-hal yang masih kurang/belum jelas untuk dipraktekkan nanti.

c. Metode Simulasi

Metode simulasi ini diberikan kepada para peserta pelatihan dalam memberikan 
kesempatan mempraktekkan membuat kerajinan (craft) decoupage dari kotak pensil dan ;pouch anyaman.

\section{HASIL DAN PEMBAHASAN}

\subsection{HASIL}

Hasil dari kegiatan, anak-anak asuhan Yayasan Ishlahul Hayat, sangat bersemangat dan antusias dalam mengikuti penyuluhan dan pelatihan, sehingga hasil kegiatan sangat memuaskan, disamping karena belum pernah mendapatkan materi motivasi dan pelatihan kerajinan (craft) decoupage, juga karena rasa ingin tahu dan ingin berkembang dari diri anak anak itu sendiri.

Dalam pelatihan ini peserta praktek langsung membuat sendiri kerajinan (craft) decoupage dengan media tempat pensil dan pouch (tas) anyaman.

Dampak kegiatan pemberdayaaan anak anak asuhuan Yayasa Islahul Hayat Kelurahan Bambu apus Kecamatan Pamulang, melalui kerajinan (craft) decoupage akan menambah kreativitas dan ketrampilan untuk menggali potensi dan terus ditingkatkan.

Pada tahap akhir dilakukan pengujian kemampuan dengan tanya jawab dan selanjutnya dilakukan evaluasi terhadap hasil kegiatan pelatihan.

\subsection{PEMBAHASAN}

Tempat kegiatan PKM adalah di Rumah Yatim \& Dhuafa Di Jalan Mujair Raya Kelurahan Bambu Apus Kecamatan Pamulang Tangerang Selatan

\section{Hari pertama, Sabtu, 11 Juli 2020}

Kegiatannya berupa penyuluhan dengan penyampaian materi tentang kreatifitas dan motivasi di Rumah Yatim \& Dhuafa Di Jalan Mujair Raya Kelurahan Bambu Apus Kecamatan Pamulang Tangerang Selatan dengan tujuan untuk meningkatkan jiwa entrepreuneur dan percaya diri dari siswa/anak asuh Yayasan Ishlahul Hayat, selanjutnya dilakukan tahap diskusi dan tanya jawab. Penyampaian materi diberikan oleh tim PKM.

\section{Hari kedua, Minggu, 12 Juli 2020}

Kegiatan berupa pelatihan, dengan pengenalan bahan dan alat kemudian dijelaskan bagaimana teknik membuat decoupage dengan media kotak pensil dan pouch (tas) bahan anyaman.

\section{KESIMPULAN DAN SARAN 5.1 KESIMPULAN}

Membentuk enterpreneur pada anak Yayasan Ishlahul Hayat, Kelurahan Bambu Apus Kecamatan Pamulang, Tangerang Selatan melalui kerajinan (craft) decoupage menunjukkan adanya kreativitas dan ketrampilan sebagai potensi diri yang terus digali dan ditingkatkan kemampuannya.

Membangun percaya diri anak asuhan Yayasan Ishlahul Hayat Kelurahan Bambu Apus Kecamatan Pamulang, Tangerang Selatan yaitu dengan membina kemampuan berkreasi dan pengembangan kreatifitas lainnya

Melalui pelatihan kerajinan (craft) dapat menambah kereatifitas pada anak asuhan Yayasan Ishlahul Hayat Kelurahan Bambu Apus Kecamatan Pamulang, sehingga menumbuhkan jiwa entrepeneur dan membangun percaya diri sehingga siap menghadapi tantangan masa depan

\subsection{SARAN}

Adanya pelatihan-pelatihan keterampilan lain untuk menggali atau meningkatkan potensi/kemampuan yang sudah ada, seperti keahlian merajut dan lainnya.

Perlu adanya pelatihan usaha lainnya seperti pemasaran melalui E-Commerce.

\section{DAFTAR PUSTAKA}

Andriani, Jeni, R. Wulansari, SR Sampurnaningsih, Nofiar, F. Sabina. 2020. Pemberdayaan Ibu PKK RW 05 Kelurahan Kunngan 


\section{Loyalitas Kreativitas \\ Aldi Masyarakat Kreatif}

P-ISSN 2722-2101, E-ISSN 2722-4201

Program Studi Ekonomi Manajemen Universitas

Pamulang

Jurnal LOKABMAS Kreatif Vol. 01, No. 03, Hal. 7-15

Email:jurnalkreatif.manajemen@gmail.com
Barat Jakarta Selatan Melalui Pelatihan Manajemen Usaha Kerajinan (Craft) Decoupage Untuk Meningkatkan Ekonomi Keluarga. Jurnal Lokabmas Kreatif 1 (1). $15-20$

Ambar, Teguh Sulistiyani. 2004. Memahami Good Governanc e: Dalam Perspektif Sumber Daya Manusia, Yogyakarta : Gaya Media

Depdiknas. 2003. Kamus Besar Bahasa Indonesia, Edisi Ketiga, Jakarta: Penerbit Balai Pustaka.

Elburdah, R. P., \& Oktrima, B. (2020). PENGARUH COMMUNITY OF PRACTICE PADA IMPLEMENTASI KNOWLEDGE MANAGEMENT PADA KANTOR KELURAHAN REMPOA. JURNAL LOKABMAS KREATIF, 1(2), 11-15.

Griffin, Ricky W.2005. Bisnis Inernasional : Perspektif Manajerial. Jakarta : Indeks

Nurwita, N., Susanti, F., Permada, D. N. R., \& Oktrima, B. (2020). DAMPAK BURUK PEMAKAIAN MEDIA SOSIAL TERHADAP SEMANGAT DAN CAPAIAN BELAJAR SISWA SMP ARRAISIYAH PAMULANG". Jurnal ABDIMAS Tri Dharma Manajemen, 1(1).

Pasaribu, V. L. D., Susanti, F., \& Hartuti, E. T. K. (2019). Memotivasi Siswa dan Siswi SMK Letris Indonesia di Dalam Menentukan Pilihan Untuk Melanjutkan Pendidikan Atau Bekerja Setelah Lulus Sekolah. Jurnal Pengabdian Dharma Laksana, 1(2), 161-172.

Pasaribu, V. L. D., Elburdah, R. P., Sudarso, E., \& Fauziah, G. (2020). PENGGUNAAN MANAJEMEN WAKTU TERHADAP PENINGKATAN PRESTASI BELAJAR DI SMP ARAISIYAH. Jurnal ABDIMAS Tri Dharma Manajemen, 1(1).
Pasaribu, V. L. D., Agrasadya, A., Shabrina, N., \& Krisnaldy, K. (2020). MENJADI ENTERPRENEUR MUDA YANG MEMILIKI JIWA LEADERSHIP UNTUK MENGHADAPI MASA DEPAN. Abdi Laksana, 1(1).

Pasaribu, V. L. D., Sulaiman, S., Sutiman, S., Thaharudin, T., \& Purnomo, B. Y. (2020). PENGENALAN LETAK POSYANDU TERDEKAT DIKELURAHAN PISANGAN DENGAN MANAJEMEN PEMASARAN REVOLUSI 4.0 UNTUK MENINGKATKAN PENGETAHUAN MASYARAKAT LETAK DAN FUNGSI POSYANDU TERDEKAT PADA KELURAHAN PISANGAN. DEDIKASI PKM, l(1), 105-110.

Priadi, A., Pasaribu, V. L. D., Virby, S., Sairin, S., \& Wardani, W. G. (2020). PENGUATAN EKONOMI KREATIF BERBASIS SUMBER DAYA DESA DIKELURAHAN REMPOA. Abdi Laksana, 1(3), 356-358.

Qurbani, D., Utomo, S. B., Maulida, H., Supardi, S., \& Oktrima, B. (2020). MOTIVASI UNTUK MENINGKATKAN KINERJA SUMBER DAYA MANUSIA PADA KELURAHAN PISANGAN. Jurnal ABDIMAS Tri Dharma Manajemen, 1(2).

Tjandra, Hendraidjat. 2016. Berkreasi Berbagi Teknik Decoupage Bersama Inspiration Craft. Jakarta : Gramedia Pustaka Utama

Zimmerer, Thomas W. 2008. Kewirausahaan dan Manajemen Usaha Kecil. Jakarta : Salemba Empat

\section{LAMPIRAN PELAKSANAAN KEGIATAN} PHOTO 


\section{Loyalitas Kreativitas}

Aldi Masyarakat Kreatif
P-ISSN 2722-2101, E-ISSN 2722-4201

Program Studi Ekonomi Manajemen Universitas

Pamulang

Jurnal LOKABMAS Kreatif Vol. 01, No. 03, Hal. 7-15

Email:jurnalkreatif.manajemen@gmail.com
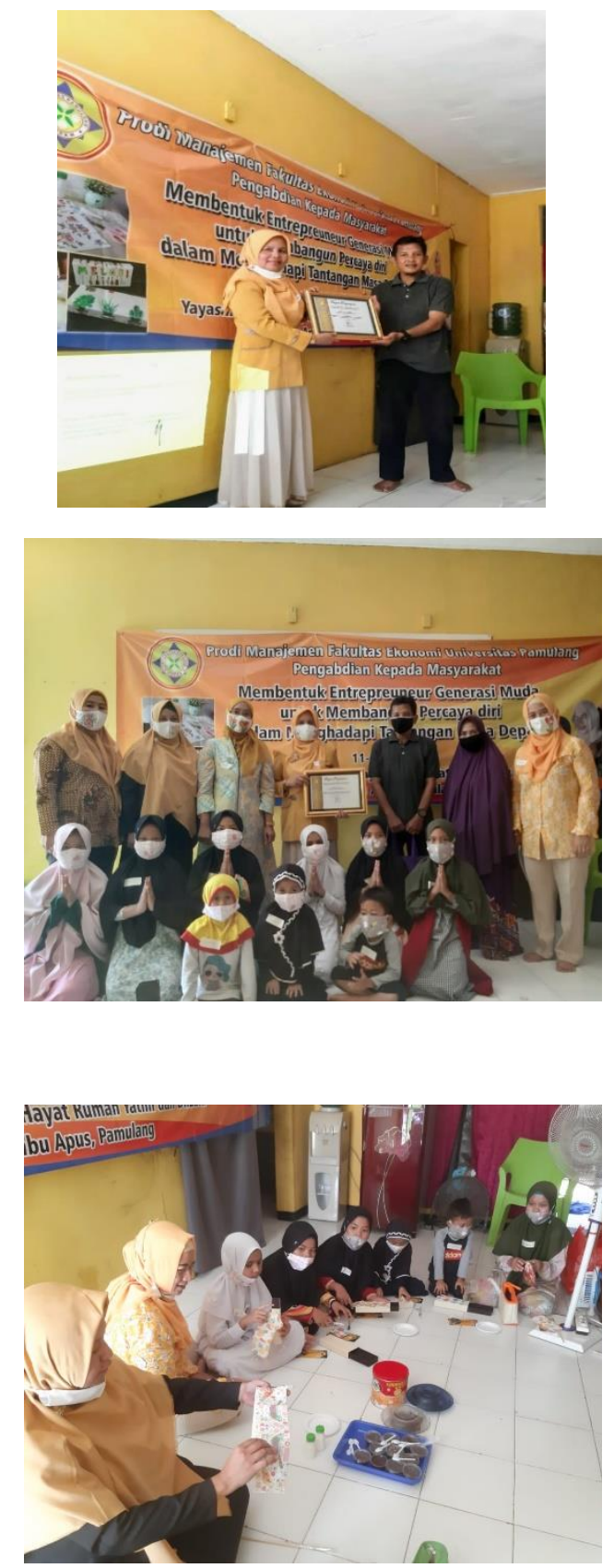

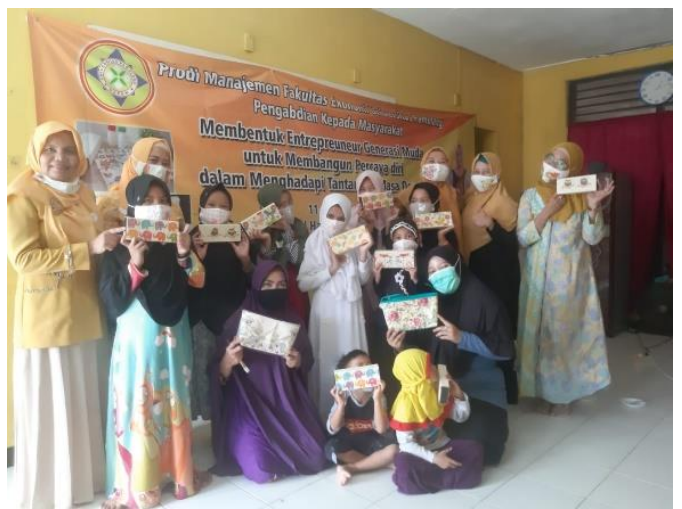

